\title{
Do Errors Matter? \\ The effects of actual and perceived L2 English errors in writing on native and non-native English speakers' evaluations of the text, the writer and the persuasiveness of the text
}

\author{
Brigitte Planken ${ }^{1, *}$, Frank van Meurs ${ }^{1} \&$ Karin Maria ${ }^{1}$ \\ ${ }^{1}$ Communication and Information Studies / Centre for Language Studies, Radboud University, the Netherlands \\ *Correspondence: Communication and Information Studies, Radboud University, Erasmusplein 1, 6525 HT, \\ Nijmegen, The Netherlands. Tel: 31-24-361-6212. E-mail: b.planken@let.ru.nl
}

Received: June 28, 2018

Accepted: August 10, 2018 Online Published: November 20, 2018

doi:10.5430/ijelt.v6n1p1

URL: https://doi.org/10.5430/ijelt.v6n1p1

\begin{abstract}
Building on studies of L1 error effects in writing, the present study aimed to gain further insight into the communicative consequences of actual and perceived L2 errors in writing by investigating their effects beyond the evaluation of text quality. No studies of L2 writing would appear to have investigated the impact of errors on perception of the author and communicative outcomes. We investigated the effect of L2 English errors in persuasive writing on native and non-native English speakers' evaluation of the text, of the author, and of the persuasiveness of the text. Selected, authentic, errors from a corpus of petitions written in English by Dutch native speakers were included in a stimulus text. Two versions of the text were presented to (non-teacher) participants in a 2 (errors vs. no errors) by 2 (native vs. non-native judges) between-subject experimental design. It was found that, while actual error had no effect on the participants' evaluation of the text, the author, or the persuasiveness of the text, perceived error (that is, if participants thought the text contained errors) had a significant negative effect on text attractiveness and the author's trustworthiness, friendliness and competence. Thus, the findings would suggest that perceived error plays an important role in how non-teacher judges evaluate a text and its author, and, more generally, that such judges would seem to use their own standards of correctness against which to judge writing and the writer, regardless of whether the judges are native or non-native speakers.
\end{abstract}

Keywords: author evaluation, ESL writing, L2 errors, perceived errors, persuasiveness, text evaluation

\section{Introduction}

Many people around the world use English as a Foreign Language (EFL) to communicate. In a Eurobarometer survey among inhabitants of the European Union, for example, 29 per cent of the respondents for whom English was not their mother tongue reported that they used English to write on the Internet (Gallup, 2011, p. 15). EFL has features in terms of lexis, grammar and pronunciation that are different from English as spoken in Inner Circle countries, that is, "the traditional cultural and linguistic bases of English" (Kachru, 1992, p. 356), such as Australia, the UK and the USA. For instance, Edwards (2014) shows that Dutch non-native speakers of English use the progressive aspect for stative verbs where Inner Circle speakers would use simple tenses. Such deviations from Inner Circle norms are traditionally regarded as second language (L2) errors (Bartsch, 1987, as cited in Hamid \& Baldauf, 2013; see also Edwards, 2014).

Numerous studies have described and categorized the occurrence of L2 errors in different languages by learners with different L1 backgrounds (for an extensive bibliography and overview, see Spillner, 2017). Spillner notes that an important question is whether errors "interfere[.] with communication and cause[.] misunderstanding" (p. 17). This question has been addressed in a number of studies (e.g. Derwing, Rossiter, \& Ehrensberger-Dow, 2002; Green \& Hecht, 1985; Hughes \& Lascaratou, 1982; Khalil, 1985; Piazza, 1980; Sheorey, 1986; see Rifkin \& Roberts, 1995, 
and Roberts \& Cimasko, 2008, pp. 126-129, for overviews). Roberts and Cimasko (2008) point out that the effects of L2 errors on attitudes towards the text and text quality have been investigated in terms of, for example, "comprehensibility, acceptability and naturalness" (p. 126; see also Khalil, 1985, p. 336). Some studies have also measured irritation associated with L2 errors (e.g. Piazza, 1980).

Flowerdew (2008) has suggested that L2 errors may have communicative effects beyond text evaluation. In a discussion of the possible stigma associated with those writing English as an additional language as academics, he observes that "'non-standard' English may be perceived as indicative of some negative characteristic such as laziness, lack of education, low intelligence, etc." (p. 80). The idea that L2 errors may have broader effects on reader perception is in line with studies of the effects of L1 errors. The theoretical starting point for these studies is that language errors provide readers or listeners with potential cues to inform their evaluation of more general characteristics of language users. Kreiner, Schnakenberg, Green, Costello and McClin (2002) remark that "because language represents an important cognitive ability, we tend to make attributions about people's general cognitive abilities based on their language performance" (p. 6). Other authors have similarly suggested that language errors can lead to negative perceptions of the writer. For example, Jessmer and Anderson (2001) and Kloet, Renkema and van Wijk (2003) argue that violations of social and cultural expectations and norms concerning aspects of language usage may negatively affect a language user's image. Language errors may constitute such violations. In general terms, Kloet et al. remark that "incompetence at the level of the message is projected onto the sender of the message him or herself" (Kloet et al., 2003, p. 271: our translation). More specifically, Jessmer and Anderson (2001) observe that "poor grammar and misspellings can imply that the sender is uneducated and hence of low status" (p. 333). In yet other studies of L1 errors in writing, language errors have been linked to another communicative effect, namely reduced persuasiveness. Mozafari, El-Alayli, Kunemund and Fry (2017), based on the Elaboration Likelihood Model of persuasion (Petty \& Cacioppo, 1981), argue that language errors in a text can serve as cues that cause readers to attribute lower credibility to the writer, which, in turn, may make the text less convincing.

The findings from L1 error studies would generally seem to offer empirical support for the theoretical reasoning that errors affect not only readers' evaluation of the text (e.g., Figuerdo \& Varnhagen, 2005; Jansen, 2010, 2012) but also of the writer (e.g., Brandenburg, 2015; Figuerdo \& Varnhagen, 2005; Jessmer \& Anderson, 2001; Kreiner et al., 2002; McAndrew \& de Jonge, 2011; Vignovic \& Thompson, 2010), and the persuasiveness of the text (e.g., Jansen, 2010, 2012; Mozafari et al., 2017; Stiff, 2012). Jansen (2010), for instance, found that spelling, punctuation and syntactic errors in direct mail letters negatively affected text evaluation (attractiveness of the text), while Jessmer and Anderson (2001) established that spelling, punctuation and grammar errors in e-mail messages had a negative influence on the readers' perceptions of the writer (status, power, competency, friendliness, likeability). With regard to persuasiveness, Mozafari et al. (2017) found that spelling and grammar errors in advertisements for business services led readers to be less inclined to use the service (car oil change or computer updating service).

A number of L1 error studies have also revealed the potential role of error perception. Mozafari et al. (2017) show that for a computer updating service advertisement including errors, readers who did not perceive these errors were more inclined to use the service advertised than readers who (correctly) perceived the errors and readers who did not perceive errors in the error-free version of the advertisement. Raedts and Roozen (2015) found that for product recall advertisement versions that contained errors, readers who did not perceive these errors evaluated the texts, the company behind the text, and the product advertised more positively, and expressed a higher purchase intention, than readers who did perceive errors. Conversely, for the error-free version of the recall advertisement, readers who perceived errors evaluated these aspects more negatively than readers who did not perceive errors.

Building on studies of L1 error effects in writing, the present study aimed to gain further insight into the communicative consequences of actual and perceived L2 errors in writing by investigating their effects beyond the evaluation of text quality, that is, in terms of perception of the author and persuasiveness as well. The expectation that L2 errors in writing could influence readers' perceptions rests on the assumption that receivers of messages use native speaker norms to evaluate communication. At the same time, there has been a growing realization in applied linguistics that as the global community of English users includes more and more non-native speakers, deviations from native speaker norms do not necessarily interfere with communicative success. According to Seidlhofer (2011), "non-conformity of form does not at all preclude functional effectiveness" (p. 127). The relevance of problematizing the role of native speaker norms to L2 writing research and pedagogy has been stressed by Ortega and Carson (2010). As far as we know, it has yet to be determined whether and to what extent L2 errors, as deviations from the native speaker norm, interfere with communicative effectiveness.

As studies of the effects of L2 errors in writing have shown that there may be differences between native speaker 
(NS) and non-native speaker (NNS) judges, and more particularly that native speakers tend to be more lenient (e.g. Green \& Hecht, 1985; Hughes \& Lascaratou, 1982; Sheorey, 1986), the present study involved both types of judges. An additional motivation was that non-native speaker receivers of English texts have become an increasingly important readership. For instance, a Eurobarometer survey among EU inhabitants showed that 48 per cent of respondents with a first language other than English used English to read or watch Internet content (Gallup, 2011, p. 11).

By investigating the impact of L2 errors in persuasive texts on target groups who may realistically be expected to read and respond to such texts, the current study aimed to extend studies of response to L2 writing in terms of teacher feedback, to encompass what impressions L2 writing makes on readers in the "real world" outside the classroom. Insights into this type of response are useful, because ultimately L2 users will have to be prepared to function in private and work contexts in society at large.

On the basis of the above considerations, the following research question was formulated:

What is the effect of actual and perceived L2 errors in written persuasive texts in English on native and non-native English speakers' evaluation of (1) the text, (2) the author, and (3) the persuasiveness of the text?

\section{Method}

In an experiment, L1 and L2 (German) speakers of English evaluated one of two versions of a persuasive text: one without and one with errors produced by (Dutch) L2 writers of English. A questionnaire was used to measure the effects of L2 errors, perceived error and judges' native tongue on text evaluation, author evaluation and persuasiveness of the text.

\subsection{Material}

Twenty-one L1 speakers of Dutch (eight males and thirteen females) wrote a persuasive text, a petition in English to make free downloading legal (mean age $=23.7$; $\min .=18$; $\max =27$ ). This topic was assumed to be relevant for people in the age group the writers and the judges in the experiment belonged to. Writers were instructed (in Dutch) as to what content the petition should include (e.g. what the organisation was and what the communicative aim of the petition was, that is, to persuade the reader to sign the petition). All participants held at least a Bachelor's degree. Three coders (L1 speakers of Dutch with near-native proficiency in English, one of whom was a teacher of English at a Dutch university) identified and categorized errors in the resulting texts. We followed the definition of non-native linguistic error given by Lennon (1991): "A linguistic form or combination of forms which, in the same context and under similar conditions of production, would, in all likelihood, not be produced by the speakers' native speaker counterparts" (p. 182). In other words, the errors we identified can be regarded as deviations from the native norm. On the basis of Green and Hecht (1985), three types of error were categorized: grammatical, vocabulary and spelling errors. Based on the errors encountered in the corpus, we added punctuation errors as a category. The errors classified were all errors that related to lower-order language knowledge, and not to higher-order discourse knowledge (cf. Gentil, 2005, 2011). Such lower-order language errors were also the focus of the L1 error effect studies discussed in the introduction.

A composite text was created on the basis of various sentences (including sentences with errors) from the corpus of 21 petitions written by the Dutch writers of English. Two versions of the text were created: one with errors and one without errors. The most frequent errors identified in the corpus, representing each of the four categories (grammatical, vocabulary, spelling, and punctuation), were included in the 'with errors' stimulus text for the experiment. A number of these errors have been identified as typical Dutch learner errors in textbooks of English for Dutch learners, which underlines their status as systematic deviations in learner language.

In the grammatical error category, the use of a simple present instead of a progressive (a common grammatical error for Dutch users of English; cf. MacKenzie, 2002, pp. 48-51) was included twice in the text version with errors: 'We all know the music and film industry suffers a lot these days' instead of 'We all know the music and film industry is suffering a lot these days' and 'Recently downloading gets more and more important to people...' instead of 'Recently downloading is getting more and more important to people...'. The second type of grammatical error included was a preposition error, namely 'convince for' instead of 'convince of'. For learners of English, preposition errors are fairly common (cf. Leki, Cumming, \& Silva, 2008, p. 170; Tetreault \& Chodorow, 2008), also for Dutch learners of English (Koning \& van der Voort, 1984, pp. 162-167). To represent the punctuation error category, two types of error were included in the text version with errors. One was the incorrect use of the hyphen in 'music- and film industry', an error typical of Dutch writers of English (Burrough-Boenisch, 2004, p. 75). Three instances of this 
error were included in the text version with errors. The second type of punctuation error was the use of a full stop instead of a comma to indicate thousands in numbers (e.g. ' 10.000 ' instead of '10,000'). Again, this is an error typically made by Dutch writers of English (cf. Cook \& Gibb, 2003, p. 192; Koning \& Van der Voort, 1984, p. 145; Lemmens \& Parr, 1995, p. 332). Two instances of this error were included in the text version with errors. From the vocabulary error category, one error was included, namely the use of 'as' instead of 'such as' to introduce an example ('sites as Youtube'). This specific error is mentioned in a usage guide for Dutch learners of English (Cleton \& Carroll, 2001, p. 35). Finally, to represent the spelling error category, two errors were included: 'benefital' instead of 'beneficial' and 'aspect to' instead of 'expect to'.

In all, the experimental version of the text (186 words) included six error types across four error categories (11 instances of error). This proportion of errors (ca. 6\%) was similar to that used in the stimulus material in study 2 conducted by Kreiner et al. (2002), in which L1 errors were found to affect perceptions of the writer's ability. The text version without errors was identical to the text with errors but with the errors corrected (see the Appendix).

\subsection{Participants}

The participants $(N=133)$ were L1 (NS) English speakers $(n=62)$ and L2 (NNS) English speakers whose L1 was German $(n=71)$. Of the L1 English speakers, the majority were from the UK (37), and the remainder were from Germany (1), Jamaica (1), Canada (2), the Netherlands (3), Australia (7) or the United States (11). Most of the L2 English speakers were from Germany (67), while three were from Switzerland, and one was from Luxembourg. The sample consisted of 78 females (59\%: 35 English-speaking and 43 German-speaking) and 55 males (41\%: 27 English-speaking and 28 German-speaking). The average age of the participants, or judges, was 23.7 ( $\min =18$; $\max$ $=33$ ). The large majority were highly educated: 81 held a Bachelor's degree, 24 a Master's degree, and the remainder (28) had at least finished high school (or equivalent education). There was no relation between text version and gender $(\chi 2(1)=.06, p=.80)$, text version and education $(\chi 2(2)=.81, p=.67)$, and text version and age $(t(131)=.02, p=.98)$.

Initially, a total of 154 judges took part in the experiment. The data of 21 of these were excluded from the analysis because they did not complete the questionnaire (12 participants) or were not native speakers of English or German (nine participants).

\subsection{Design}

The experiment had a 2 (text version: with or without errors) x 2 (judges' L1: English or German) x 2 (error perception: yes or no) between-subject design.

\subsection{Instrumentation}

In an online questionnaire, seven-point semantic differentials were used to measure evaluation of the text, the author and the persuasiveness of the text (based on Hornikx, van Meurs, \& Hof, 2013; Kloet et al., 2003; Maes, Ummelen, \& Hoeken, 1996, p. 209; Nejjari, Gerritsen, van der Haagen, \& Korzilius, 2012; Smakman et al., 2009).

\subsubsection{Text Evaluation}

Text evaluation was measured in terms of comprehensibility and attractiveness. Two semantic differentials were included in the questionnaire to gauge comprehensibility: easy/difficult and simple/complicated $(\alpha=.72)$. Attractiveness was measured with five semantic differentials: fascinating/boring, nice to read/ not nice to read, interesting/uninteresting, pleasant/irritating, and attractive/not attractive $(\alpha=.83)$. The items for comprehensibility and attractiveness were presented in mixed order.

\subsubsection{Author Evaluation}

Three aspects of author evaluation were measured: trustworthiness, friendliness, and competence. Trustworthiness was measured with three semantic differentials: honest/dishonest, reliable/unreliable, and sincere/insincere $(\alpha=.74)$. Four semantic differentials were included to gauge friendliness: friendly/unfriendly, considerate/ aggressive, direct/indirect, and pleasant/irritating $(\alpha=.72)$. Competence was measured on the basis of four semantic differentials: competent/ incompetent, no authority/ authority, intelligent/ stupid, and educated/ uneducated $(\alpha=.78)$. The items for trustworthiness, friendliness and competence were presented in mixed order.

\subsubsection{Persuasiveness of the Text}

Persuasiveness of the text, operationalized in terms of readers' intention to sign the petition, was measured with four statements $(\alpha=.91)$ : 'I would sign this petition' (likely/unlikely); 'I would ask my friends to sign this petition' (likely/unlikely); 'I find signing this petition (wise/unwise)'; 'This petition (appeals to me/does not appeal to me)'. 


\subsubsection{Error Perception}

The following yes/no question was asked to determine whether the participants perceived errors in the text version they were presented with: 'Did you come across errors while reading the text?' (yes/no). In addition, participants were asked to indicate the errors they had seen by typing or copy-pasting from the text the errors into an answer box (open question). In order to determine to what extent the participants perceived the (actual) errors included in the with-error version of the text, and/or other errors, participants' responses were categorized independently by two coders. The following error categories were found to be applicable: lexicogrammatical, and discourse, that is, style, errors (cf. Gentil, 2011). Responses that could not be categorized into one of the two types were labelled undeterminable.

\subsubsection{Background Variables}

Multiple choice and open-ended questions were used to collect biodata on age, gender, nationality, native language, and highest educational level.

\subsection{Procedure}

Participants were either approached on campus at Radboud University (the Netherlands), University of Westminster, and University of London (UK), or through the websites Couchsurfing.net, Aveneca.com/cbb/, Thestudentroom.co.uk, UKchatterbox.com, and Usingenglish.com. Participants who agreed to take part in the study received a digital link which gave access to the online questionnaire.

\subsection{Statistical Treatment}

Three-way ANOVAs were conducted to explore the impact of actual L2 errors, judges' L1, and perceived error on the three dependent variables. Chi-square tests were performed to examine if participants differed in error perception across text version and judges' L1, and to test for differences in gender and education level between the two text versions. A t-test was carried out to test for differences in age distribution between the text versions.

\section{Results}

First, the extent to which the judges perceived errors in the different versions of the text (with or without errors) will be reported. Second, we present the effects of actual versus perceived error on text evaluation, author evaluation and persuasiveness of the text.

\subsection{Error Perception}

The participants were asked to indicate whether they detected any errors in the text version they were presented with. Table 1 shows the number of judges in each group (NS versus NNS judges) who reported detecting errors or not in the two text versions.

Table 1. Error Perception as a Function of Text Version and Judges' L1 $(N=133)$

\begin{tabular}{lllll}
\hline Text version & & Judges' L1 & & \\
\hline with errors & & NS English judges & NNS English judges & All judges \\
error perception & yes & 23 & 13 & 36 \\
& No & 8 & 23 & 31 \\
& total & 31 & 36 & 67 \\
without errors & & & & \\
error perception & yes & 9 & 7 & 16 \\
& no & 22 & 28 & 50 \\
both text versions & total & 31 & 35 & 66 \\
error perception & & & & 52 \\
& yes & 32 & 20 & 81 \\
& no & 30 & 51 & 133 \\
\hline
\end{tabular}


A significant association was found between text version and error perception $\left(\chi^{2}(1)=10.93, p<.05\right)$. Significantly more participants (regardless of their L1) detected errors in the text version with errors than in the text version without errors, which indicates that the manipulation was successful. Furthermore, for the version with errors, a significant association was found between L1 and error perception $\left(\chi^{2}(1)=8.25, p<.05\right.$, Cramer's V $\left.=.38\right)$. Significantly more L1 English speaking (NS) participants detected errors than did L2 English speaking (NNS) participants. Finally, for the version without errors, no significant association was found between judges' L1 and error perception $\left(\chi^{2}(1)=0.32, p=.57\right)$.

With respect to the different text versions, the analysis revealed that in the with-error version, the vast majority of participants (29) who noted errors (31) indeed identified at least one or some of the manipulated, lexicogrammatical errors included by the researchers, which further suggests that the manipulation was successful. Of the participants who described the errors they saw in the with-error version, 22 were NS judges and nine were NNS judges.

With respect to the error-free version, 12 participants (seven NS judges and five NNS judges) described errors they perceived. Four participants described errors that could be classified as lexicogrammatical (e.g. the incorrect use of a comma), three described a stylistic error (e.g. "getting should be becoming"), and seven described errors whose nature the researchers could not determine based on the participants' descriptions.

\subsection{Text Evaluation}

Table 2. Text Evaluation, in terms of Comprehensibility and Attractiveness, as a Function of Text Version, Error Perception and Judges' L1 $(N=133)(1=$ not comprehensible $/$ attractive; $7=$ comprehensible $/$ attractive $)$

\begin{tabular}{|c|c|c|c|c|c|c|c|}
\hline \multicolumn{8}{|c|}{ Comprehensibility } \\
\hline Text version & & NS judges & & NNS judges & & All judges & \\
\hline with errors & & $M$ & $S D$ & $M$ & $S D$ & $M$ & $S D$ \\
\hline \multirow[t]{3}{*}{ error perception } & yes & 5.28 & 1.76 & 5.46 & 1.38 & 5.35 & 1.62 \\
\hline & no & 5.50 & 1.23 & 5.52 & 1.37 & 5.52 & 1.31 \\
\hline & total & 5.34 & 1.63 & 5.50 & 1.35 & 5.43 & 1.48 \\
\hline \multicolumn{8}{|l|}{ without errors } \\
\hline \multirow[t]{3}{*}{ error perception } & yes & 5.39 & 1.24 & 4.93 & 1.40 & 5.19 & 1.29 \\
\hline & no & 6.14 & 0.89 & 5.61 & 1.05 & 5.84 & 1.01 \\
\hline & total & 5.92 & 1.04 & 5.47 & 1.14 & 5.68 & 1.11 \\
\hline \multicolumn{8}{|l|}{ both versions } \\
\hline \multirow[t]{3}{*}{ error perception } & yes & 5.31 & 1.62 & 5.28 & 1.37 & 5.30 & 1.51 \\
\hline & no & 5.97 & 1.01 & 5.57 & 1.19 & 5.72 & 1.14 \\
\hline & total & 5.63 & 1.39 & 5.49 & 1.24 & 5.55 & 1.31 \\
\hline \multicolumn{8}{|l|}{ Attractiveness } \\
\hline \multirow{5}{*}{$\begin{array}{l}\text { Text version } \\
\text { with errors } \\
\text { error perception }\end{array}$} & & NS judges & & NNS judges & & All judges & \\
\hline & & $M$ & $S D$ & $M$ & $S D$ & $M$ & $S D$ \\
\hline & yes & 3.66 & 1.37 & 3.65 & 0.78 & 3.66 & 1.18 \\
\hline & no & 3.85 & 1.82 & 4.21 & 1.12 & 4.12 & 1.31 \\
\hline & total & 3.71 & 1.47 & 4.01 & 1.04 & 3.87 & 1.25 \\
\hline \multicolumn{8}{|l|}{ without errors } \\
\hline \multirow[t]{3}{*}{ error perception } & yes & 3.58 & 0.85 & 3.37 & 1.23 & 3.49 & 1.00 \\
\hline & no & 4.25 & 1.06 & 3.73 & 0.85 & 3.96 & 0.97 \\
\hline & total & 4.05 & 1.04 & 3.66 & 0.93 & 3.84 & 0.99 \\
\hline \multicolumn{8}{|l|}{ both versions } \\
\hline \multirow[t]{3}{*}{ error perception } & yes & 3.64 & 1.23 & 3.55 & 0.94 & 3.60 & 1.12 \\
\hline & no & 4.14 & 1.28 & 3.95 & 1.00 & 4.02 & 1.11 \\
\hline & total & 3.88 & 1.27 & 3.83 & 0.99 & 3.86 & 1.13 \\
\hline
\end{tabular}


Text evaluation was measured in terms of the attractiveness and comprehensibility of the text. Levene's test was not significant for attractiveness $(p=.06)$ but significant for comprehensibility $(p<.05)$. To evaluate the results of the two-way ANOVA concerning comprehensibility, the significance level was therefore set at .01, following Pallant (2007, p. 261). Table 2 shows the means and standard deviations of scores on text comprehensibility and text attractiveness as a function of text version (with/without errors), error perception, and judges' L1 (NSs versus NNSs).

There were no significant main effects of text version $(F(1,124)<1)$, judges' $\mathrm{L} 1(F(1,124)<1)$, and error perception $(F(1,124)=2.73, p=.101)$ on comprehensibility. No significant interaction effects on text comprehensibility were found for text version and judges' $\mathrm{L} 1(F(1,124)=1.33, p=.251)$, text version and error perception $(F(1,124)=1.24, p=.268)$, judges' L1 and error perception $(F(1,124)<1)$, or of all three factors $(F(1$, 124) $<1)$.

With respect to text attractiveness, no significant main effects were found of text version $(F(1,124)<1)$ or judges' L1 $(F(1,124)<1)$. However, there was a main effect of error perception $\left(F(1,124)=4.02, p=.047, \eta^{2}=.03\right)$. When the participants detected errors in the text, they thought that the text was less attractive $(M=3.60, S D=1.12)$ than when the participants did not detect errors $(M=4.02, S D=1.11)$. Finally, the interaction effects of text version and judges' L1 $(F(1,124)=1.45, p=.31)$, text version and error perception $(F(1,124)<1)$, judges' L1 and error perception $(F(1,124)<1)$, or of all three factors on text attractiveness $(F(1,124)<1)$ were found not to be significant.

\subsection{Author Evaluation}

Author evaluation was measured in terms of author's trustworthiness, friendliness, and competence. Levene's test was not significant for the variables trustworthiness $(p=.56)$, friendliness $(p=.87)$, and competence $(p=.18)$. Therefore, it can be assumed that the variances were roughly equal. Table 3 shows the means and standard deviations of scores on the trustworthiness, friendliness and competence of the author as a function of text version (with/without errors), error perception, and judges' L1 (NSs versus NNSs).

No significant main effects were found of text version $(F(1,124)=2.32, p=.130)$ and judges' $L 1(F(1,124)=2.89$, $p=.092)$ on author's trustworthiness. However, there was a significant main effect of error perception $(F(1,124)=$ $\left.5.39, p=.022, \eta^{2}=.04\right)$. When the participants thought the text contained errors, the author was perceived as less trustworthy $(M=4.11, S D=1.05)$ than when they thought the text did not contain errors $(M=4.42, S D=0.99)$. There were no significant interaction effects of text version and judges' $L 1(F(1,124)=1.26, p=.263)$, text version and error perception $(F(1,124)<1)$, judges' L1 and error perception $(F(1,124)<1)$, or of all three factors on the author's trustworthiness $(F(1,124)<1)$.

With respect to author friendliness, no significant main effects were found of text version $(F(1,124)=2.35, p=.128)$ or judges' L1 $(F(1,124)<1)$. However, there was a significant main effect of error perception $(F(1,124)=7.94, p$ $\left.=.006, \eta^{2}=.06\right)$. When the participants detected errors in the text, the author was perceived as less friendly $(M=$ $4.36, S D=1.01)$ than when the participants did not detect errors in the text $(M=4.79, S D=0.93)$. There were no significant interaction effects of text version and judges' $\mathrm{L} 1(F(1,124)=1.18, p=.279)$, text version and error perception $(F(1,124)<1)$, judges' L1 and error perception $(F(1,124)<1)$, or of all three factors on author friendliness $(F(1,124)<1)$.

Finally, with regard to author competence, the main effects of text version $(F(1,124)=2.71, p=.102)$ and judges' L1 $(F(1,124)=1.30, p=.256)$ were not significant. Again, however, the main effect of error perception was found to be significant $\left(F(1,124)=12.66, p=.001, \eta^{2}=.09\right)$. When the participants detected errors in the text, the author was perceived as less competent $(M=3.74, S D=1.07)$ than when the participants did not detect errors in the text $(M$ $=4.30, S D=0.94)$. There were no significant interaction effects of text version and judges' $L 1(F(1,124)<1)$, text version and error perception $(F(1,124)<1)$, judges'L1 and error perception $(F(1,124)=2.35, p=.128)$, or all three factors on the author's competence $(F(1,124)<1)$. 
Table 3. Author Evaluation, in terms of Trustworthiness, Friendliness, and Competence, as a Function of Text Version, Error Perception and Judges' L1 $(N=133)(1=$ not trustworthy / friendly / competent; 7 = trustworthy / friendly / competent)

\begin{tabular}{|c|c|c|c|c|c|c|c|}
\hline \multicolumn{8}{|l|}{ Trustworthiness } \\
\hline Text version & & NS judges & & NNS judges & & All judges & \\
\hline with errors & & $M$ & $S D$ & $M$ & $S D$ & $M$ & $S D$ \\
\hline \multirow[t]{3}{*}{ error perception } & yes & 4.17 & 1.25 & 4.23 & 0.57 & 4.19 & 1.05 \\
\hline & no & 4.79 & 0.93 & 4.51 & 0.86 & 4.58 & 0.87 \\
\hline & total & 4.33 & 1.19 & 4.41 & 0.77 & 4.37 & 0.98 \\
\hline \multicolumn{8}{|l|}{ without errors } \\
\hline \multirow[t]{3}{*}{ error perception } & yes & 4.11 & 1.13 & 3.67 & 0.98 & 3.92 & 1.06 \\
\hline & no & 4.70 & 1.02 & 4.02 & 1.01 & 4.32 & 1.06 \\
\hline & total & 4.16 & 1.20 & 4.03 & 0.76 & 4.11 & 1.05 \\
\hline \multirow{4}{*}{$\begin{array}{l}\text { both versions } \\
\text { error perception }\end{array}$} & & & & & & & \\
\hline & yes & 4.16 & 1.20 & 4.03 & 0.76 & 4.11 & 1.05 \\
\hline & no & 4.72 & 0.98 & 4.24 & 0.96 & 4.42 & 0.99 \\
\hline & total & 4.43 & 1.13 & 4.18 & 0.91 & 4.30 & 1.02 \\
\hline \multicolumn{8}{|l|}{ Friendliness } \\
\hline \multirow{5}{*}{$\begin{array}{l}\text { Text version } \\
\text { with errors } \\
\text { error perception }\end{array}$} & & NS judges & & NNS judges & & All judges & \\
\hline & & $M$ & $S D$ & $M$ & $S D$ & $M$ & $S D$ \\
\hline & yes & 4.39 & 1.02 & 4.65 & 0.78 & 4.49 & 0.94 \\
\hline & no & 4.94 & 0.87 & 4.83 & 0.85 & 4.85 & 0.85 \\
\hline & total & 4.53 & 1.00 & 4.76 & 0.82 & 4.66 & 0.91 \\
\hline \\
\hline & yes & 4.25 & 1.18 & 3.86 & 1.13 & 4.08 & 1.14 \\
\hline \multirow{2}{*}{ error perception } & no & 4.91 & 1.12 & 4.63 & 0.85 & 4.75 & 0.98 \\
\hline & total & 4.72 & 1.16 & 4.47 & 0.94 & 4.59 & 1.05 \\
\hline \multirow{4}{*}{$\begin{array}{l}\text { both versions } \\
\text { error perception }\end{array}$} & & & & & & & \\
\hline & yes & 4.35 & 1.05 & 4.38 & 0.97 & 4.36 & 1.01 \\
\hline & no & 4.92 & 1.05 & 4.72 & 0.85 & 4.79 & 0.93 \\
\hline & total & 4.63 & 1.08 & 4.62 & 0.89 & 4.62 & 0.98 \\
\hline \multicolumn{8}{|l|}{ Competence } \\
\hline \multirow{5}{*}{$\begin{array}{l}\text { Text version } \\
\text { with errors } \\
\text { error perception }\end{array}$} & & NS judges & & NNS judges & & All judges & \\
\hline & & $M$ & $S D$ & $M$ & $S D$ & $M$ & $S D$ \\
\hline & yes & 3.68 & 1.34 & 4.04 & 0.68 & 3.81 & 1.15 \\
\hline & no & 4.78 & 0.95 & 4.37 & 0.82 & 4.48 & 0.86 \\
\hline & total & 3.97 & 1.33 & 4.25 & 0.78 & 4.12 & 1.07 \\
\hline \multirow{4}{*}{$\begin{array}{l}\text { without errors } \\
\text { error perception }\end{array}$} & & & & & & & \\
\hline & yes & 3.67 & 0.35 & 3.46 & 1.02 & 3.58 & 0.90 \\
\hline & no & 4.55 & 0.95 & 3.92 & 0.94 & 4.20 & 0.99 \\
\hline & total & 4.29 & 0.99 & 3.83 & 0.96 & 4.05 & 0.99 \\
\hline \multirow{4}{*}{$\begin{array}{l}\text { both versions } \\
\text { error perception }\end{array}$} & & & & & & & \\
\hline & yes & 3.68 & 1.21 & 3.84 & 0.83 & 3.74 & 1.07 \\
\hline & no & 4.61 & 0.94 & 4.12 & 0.91 & 4.30 & 0.94 \\
\hline & total & 4.13 & 1.18 & 4.04 & 0.89 & 4.08 & 1.03 \\
\hline
\end{tabular}

\subsection{Persuasiveness of the Text}

Levene's test was not significant for the variable persuasiveness of the text $(p=.24)$. It can therefore be assumed that the variances were roughly equal. Table 4 shows the means and standard deviations for persuasiveness as a function of text version (with/without errors), error perception, and judges' L1 (NSs versus NNSs). 
Table 4. Persuasiveness as a Function of Text Version, Error Perception, and Judges' L1 $(N=133)(1=$ low and $7=$ high)

\begin{tabular}{|c|c|c|c|c|c|c|c|}
\hline \multicolumn{2}{|l|}{ Text version } & \multicolumn{6}{|c|}{ Judges' L1 } \\
\hline & & \multicolumn{2}{|c|}{ NS judges } & \multicolumn{2}{|c|}{ NNS judges } & \multicolumn{2}{|c|}{ All judges } \\
\hline \multirow{4}{*}{$\begin{array}{l}\text { with errors } \\
\text { error perception }\end{array}$} & & $M$ & $S D$ & $M$ & $S D$ & $M$ & $S D$ \\
\hline & yes & 3.22 & 1.96 & 3.42 & 1.35 & 3.29 & 1.75 \\
\hline & no & 3.53 & 2.00 & 3.64 & 1.48 & 3.61 & 1.59 \\
\hline & total & 3.30 & 1.94 & 3.56 & 1.42 & 3.44 & 1.67 \\
\hline \multirow[t]{3}{*}{$\begin{array}{l}\text { without errors } \\
\text { error perception }\end{array}$} & yes & 3.81 & 1.73 & 2.29 & 1.24 & 3.14 & 1.68 \\
\hline & no & 3.43 & 1.76 & 2.83 & 1.45 & 3.10 & 1.60 \\
\hline & total & 3.54 & 1.73 & 2.72 & 1.41 & 3.11 & 1.61 \\
\hline \multirow[t]{3}{*}{$\begin{array}{l}\text { both text versions } \\
\text { error perception }\end{array}$} & yes & 3.38 & 1.89 & 3.03 & 1.39 & 3.25 & 1.71 \\
\hline & no & 3.46 & 1.79 & 3.20 & 1.50 & 3.29 & 1.61 \\
\hline & total & 3.42 & 1.83 & 3.15 & 1.47 & 3.27 & 1.64 \\
\hline
\end{tabular}

The main effects of text version $(F(1,124)=1.27, p=.263)$, judges' L1 $(F(1,124)=1.94, p=.166)$, and error perception $(F(1,124)<1)$ on persuasiveness were not found to be significant, and there were no significant interaction effects of text version and judges' L1 $(F(1,124)=3.53, p=.063)$, text version and error perception $(F(1$, $124)<1)$, judges' L1 and error perception $(F(1,124)<1)$, or of all three factors on persuasiveness $(F(1,124)<1)$.

\section{Discussion}

Theory and empirical findings regarding the effects of L1 writing errors indicate that these may negatively affect readers' evaluations of a text as well as other dimensions, such as author evaluation and persuasiveness. Some studies have also shown the potential effects of perceived error on these evaluations. By extension, we argued that similar effects could be expected for L2 writing errors. However, no studies of L2 writing would appear to have investigated the potential impact of errors beyond text evaluation. The aim of the present study was to investigate the effect of actual and perceived L2 error in persuasive writing on native and non-native English readers' text evaluation, author evaluation and their evaluation of the persuasiveness of the text.

The findings of our study showed that actual L2 errors do not impact on evaluations of the text and the author of the text, nor do they affect persuasiveness. While this overall finding seems unexpected in comparison to the general findings from studies of the effects of L1 errors, it should be noted that in those studies, errors were not always found to have an impact on all the dependent variables investigated (e.g. Brandenburg, 2015; Figueredo \& Varnhagen, 2005; Jansen, 2012; Kloet et al., 2003; Kreiner et al., 2002). In the context of L1 errors, our experimental findings seem to support observations made in the literature on English as a Lingua Franca which suggest that deviations from native norms do not necessarily interfere with communicative effectiveness (Seidlhofer, 2011; see also Pitzl, 2009).

On the other hand, perceived error was found to have an effect, as it influenced a number of aspects of both text and author evaluation. When judges, regardless of whether they were NSs or NNSs of English, perceived errors, they evaluated the text as less attractive. In addition, they evaluated the author as less trustworthy, friendly and competent. This is in line with findings for the effects of perceived L1 errors in recent studies on the consequences of L1 errors in written communication (Mozafari et al., 2017; Raedts \& Roozen, 2015). Despite the fact that the actual presence of L2 errors did not seem to affect any of the dependent variables in the current study, the effects found for perceived error on text and author evaluation would seem to imply that it is important nonetheless that texts are at least seen to be error free. What seems to matter is not so much the presence of actual errors, but whether the reader thinks there are errors.

The present study found that more L1 English than L2 English (German-speaking) judges reported detecting errors in the text version with errors. This is perhaps to be expected as native speakers have a better command of the language. However, it was somewhat surprising that there were no differences between the two groups of judges with regard to the effects of L2 errors on text and author evaluation, and on text persuasiveness. This contrasts with findings from earlier studies where non-native judges were shown to be more lenient in judging non-native errors 
than native judges (Green \& Hecht, 1985; Hughes \& Lascaratou, 1982; Sheorey, 1986). This discrepancy may be explained by the fact that the comparison between native and non-native judges in earlier research has tended to involve teachers, who may be focussed on errors, whereas the current study involved non-expert (student) evaluators, who may be less sensitive to errors (cf. Hadden, 1991, and Okamura, 1995, on teacher and non-teacher evaluations of NNS speech).

As to the question whether a native norm plays a role in the evaluation of L2 writing (cf. Ortega \& Carson, 2010), our findings suggest a somewhat complex picture. Both L1 and L2 English judges to some extent identified the actual errors in the experiment, which shows that they did notice deviations from the native norm. At the same time, these deviations did not influence the judges' evaluations of the text, the author and the persuasiveness of the text. In this important regard, therefore, actual errors, that is, deviations from the native norm, do not appear to have any consequences, at least not for the L2 errors incorporated in the stimulus text and for the non-teacher judges in the present study. However, the findings also stress that perceived error does affect text and author evaluations. This strongly suggests that both native and non-native judges evaluate texts against their idea of what correct usage is, and that, if they think the text and writer deviate in some way from this intuitive standard, this leads them to negatively evaluate the author and the text.

\subsection{Limitations and Suggestions for Further Research}

The errors selected for the current experiment were based on errors actually produced in the L2 writing of highly proficient university graduates. As a result, the experimental text version with errors may have contained only a limited set of relatively less severe errors than if errors had been taken from a corpus of texts produced by less proficient learners of English. It is likely that less proficient learners of English produce relatively more errors, a potentially wider range of error types, and possibly more severe errors than proficient learners of English, such as the learners who wrote the texts on which the stimuli in the current experiment were based. By extension, it seems plausible that errors characteristic of less proficient learners of English interfere more with the way a (persuasive) text is perceived and hence have an impact on author evaluation and persuasiveness. Investigation of the effects of errors produced by proficient versus less proficient learner writers would therefore seem to be a fruitful avenue for future research. This suggestion is in line with the call made by Ortega and Carson (2010, p. 62).

The errors selected in the present experiment, although covering four distinct error types, did not include style errors, that is, inappropriate use of vocabulary in terms of register and level of formality, or errors in discourse organisation (Green \& Hecht, 1985). Errors at the level of discourse organization constitute problems in the area of higher order discourse knowledge (Gentil, 2011). It could be that these types of error have a different effect than the lexicogrammatical (lower-order) language errors included in the present experiment. In light of research on error gravity (for an overview, see Rifkin \& Roberts, 1995), future studies could investigate whether different (combinations of) L2 error types in texts affect judges' perceptions differently.

Both groups of judges in the current experiment were L1 speakers of a Germanic language (English or German) which is close to Dutch, the L1 of the writers that produced the texts from which the L2 errors were selected. Because of their shared Germanic language background, the judges may have recognized the errors and been more tolerant of them than if they had had L1s that were linguistically more distant from Dutch, German or English. Given the fact that, in domains such as academia, education and business, English as a Lingua Franca is increasingly being used among non-native speakers with various typologically different L1 backgrounds, it seems highly relevant that further research on the perception and effects of L2 errors involves writers whose L1 is a Germanic language and judges whose L1 is a Romance or Asian language, and vice versa.

\section{Conclusion}

The current study has found that actual L2 errors in English writing did not affect non-teacher readers' evaluation of the text, the author, and the persuasiveness of the text, but that perceived error (i.e. if readers thought the text contained errors) led to more negative evaluations of the attractiveness of the text and the trustworthiness, friendliness and competence of the author. The findings of the present study contribute to knowledge about response to L2 errors in writing in two ways. First, they indicate that errors, in the sense of perceived errors, affect readerships beyond the classroom, the traditional setting in which L2 writing has been evaluated and studied most frequently in earlier investigations (cf. Roberts \& Cimasko's overview, 2008, pp. 126-129). Second, the findings demonstrate that perceived errors not only impact on readers' evaluation of the L2 text (the focus of studies into effects of NNS 
writing errors to date, as was pointed out in the Introduction), but can also have a negative influence on the way an L2 writer is regarded.

\section{References}

Brandenburg, L. C. (2015). Testing the recognition and perception of errors in context. Business and Professional Communication Quarterly, 78(1), 74-93. https://doi.org/10.1177/2329490614563570

Burrough-Boenisch, J. (2004). Righting English that's gone Dutch. Voorburg: Kemper Conseil Publishing.

Cleton, P. \& Carroll, D. (2001). Kramers stijlgids Engels. No Place: Kramers Woordenboeken.

Cook, K., \& Gibb, D. (2003). Eindelijk Engels! Praktische handreiking voor het verbeteren van uw Engels. Voorburg: Kemper Conseil Publishing.

Derwing, T. M., Rossiter, M. J., \& Ehrensberger-Dow, M. (2002). 'They speaked and wrote real good': Judgements of non-native and native grammar. Language Awareness, 11(2), 84-99. https://doi.org/10.1080/09658410208667048

Edwards, A. (2014). The progressive aspect in the Netherlands and the ESL/EFL continuum. World Englishes, 33(2), 173-194. https://doi.org/10.1111/weng.12080

Figueredo, L., \& Varnhagen, C. K. (2005). Didn't you run the spell checker? Effects of type of spelling error and use of a spell checker on perceptions of the author. Reading Psychology, 26, 441-458. https://doi.org/10.1080/02702710500400495

Flowerdew, J. (2008). Scholarly writers who use English as an Additional Language: What can Goffman's "Stigma" tell us? Journal of English for Academic Purposes, 7, 77-86. https://doi.org/10.1016/j.jeap.2008.03.002

Gallup (2011). User language preferences online. Survey conducted by The Gallup Organization, Hungary upon the request of Directorate-General Information Society and Media. Flash EB Series 313. Retrieved June 20, 2018, from http://ec.europa.eu/public_opinion/flash/fl_313_en.pdf

Gentil, G. (2005). Commitments to academic biliteracy: Case studies of francophone university writers. Written Communication, 22, 421-471. https://doi.org/10.1177/0741088305280350

Gentil, G. (2011). A biliteracy agenda for genre research. Journal of Second Language Writing, 20(1), 6-23. https://doi.org/10.1016/j.jslw.2010.12.006

Green, P. S., \& Hecht, K. (1985). Native and non-native evaluation of learners' errors in written discourse. System, 13(2), 77-97. https://doi.org/10.1016/0346-251X(85)90011-9

Hadden, B.L. (1991). Teacher and nonteacher perceptions of second-language communication. Language Learning, 41(1), 1-24. https://doi.org/10.1111/j.1467-1770.1991.tb00674.x

Hamid, M. O., \& Baldauf, R. B. (2013). Second language errors and features of World Englishes. World Englishes, 32(4), 476-494. https://doi.org/10.1111/weng.12056

Hornikx, J., van Meurs, F., \& Hof, R.-J., (2013). The effectiveness of foreign-language display in advertising for congruent versus incongruent products. Journal of International Consumer Marketing, 25(3), 152-165. https://doi.org/10.1080/08961530.2013.780451

Hughes, A., \& Lascaratou, C. (1982). Competing criteria for error gravity. ELT Journal, 36(3), 175-182. https://doi.org/10.1093/elt/36.3.175

Jansen, F. (2010). Onkunde wordt bestraft. Het effect van systematisch gemaakte afwijkingen van de standaardtaal op de waardering van direct-mailbrieven. Neerlandistiek, 10(2). Retrieved on June 20, 2018, from file:///C:/Users/u654019/Downloads/article.pdf

Jansen, F. (2012). The putative email style and its explanations: Evidence from two effect studies of Dutch direct mail letters and direct marketing emails.Language@ Internet, 9(2). Retrieved June 20, 2018, from http://www.languageatinternet.org/articles/2012/Jansen

Jessmer, S.L., \& Anderson, D. (2001). The effect of politeness and grammar on user perceptions of electronic mail. North American Journal of Psychology, 3(2), 331-346.

Kachru, B. B. (1992). Models for Non-Native Englishes. In B. B. Kachru, The other tongue: English across cultures 
(2nd ed.) (pp. 48-74). Urbana: University of Illinois Press.

Khalil, A. (1985). Communicative error evaluation: Native speakers' evaluation and interpretation of written errors of Arab EFL learners. TESOL Quarterly, 19(2), 335-351. https://doi.org/10.2307/3586833

Kloet, L., Renkema, J., \& Wijk, C. van (2003). Waarom foutloos schrijven? Het effect van taalfouten op tekstwaardering, imago en overtuigingskracht. In L. van Waes, P. Cuvelier, G. Jacobs, \& I. de Ridder (Eds.), Studies in taalbeheersing 1 (pp. 270-279). Assen: Van Gorcum.

Koning, P. L., \& Voort, P. J., van der (1984). An English grammar for student teachers: A contrastive course textbook. Groningen: Wolters-Noordhoff-Longman.

Kreiner, D. S., Schnakenberg, S. D., Green, A. G., Costello, M. J., \& McClin, A. F. (2002). Effects of spelling errors on the perception of writers. The Journal of General Psychology, 129(1), 5-17. https://doi.org/10.1080/00221300209602029

Leki, I., Cumming, A., \& Silva, T. (2008). A synthesis of research on second language writing in English. New York: Routledge.

Lemmens, M., \& Parr, T. (1995). Handboek voor de vertaler Nederlands-Engels. Groningen: Wolters-Noordhoff.

Lennon, P. (1991). Error: Some problems of definition, identification, and distinction. Applied Linguistics, 12(2), 180-196. https://doi.org/10.1093/applin/12.2.180

Mackenzie, J. L. (2002). Principles and pitfalls of English grammar. Bussum: Uitgeverij Coutinho.

Maes, A., Ummelen, N., \& Hoeken, H. (1996). Instructieve teksten: Analyse, ontwerp en evaluatie. Bussum: Dick Coutinho.

McAndrew, F.T., \& De Jonge, C.R. (2011). Electronic person perception: What do we infer about people from the style of their e-mail messages? Social Psychological and Personality Science, 2(4), 403-407. https://doi.org/10.1177/1948550610393988

Mozafari, A., El-Alayli, A., Kunemund, A., \& Fry, T. (2017). Impressions of businesses with language errors in print advertising: Do spelling and grammar influence the inclination to use a business? Current Psychology, 1-7. https://doi.org/10.1007/s12144-017-9735-0

Nejjari, W., Gerritsen, M., Haagen, M. van der, \& Korzilius, H. (2012). Responses to Dutch-accented English. World Englishes, 31(2), 248-267. https://doi.org/10.1111/j.1467-971X.2012.01754.x

Okamura, A. (1995). Teachers' and nonteachers' perception of elementary learners' spoken Japanese. The Modern Language Journal, 79(1), 29-40. https://doi.org/10.1111/j.1540-4781.1995.tb05413.x

Ortega, L., \& Carson, J. (2010). Multicompetence, social context, and L2 writing research praxis. In P. Matsuda \& T. Silva (Eds.), Practicing theory in second language writing (pp. 48-71). West Lafayette, IN: Parlor Press.

Pallant, J. (2007). SPSS survival manual: A step by step guide to data analysis using SPSS for Windows (3rd ed.). Maidenhead: McGraw-Hill Education.

Petty, R. E., \& Cacioppo, J. T. (1981). Attitudes and persuasion: Classic and contemporary approaches. Dubuque, IA: Brown.

Piazza, L. G. (1980). French tolerance for grammatical errors made by Americans. Modern Language Journal, 64(4), 422-427. https://doi.org/10.1111/j.1540-4781.1980.tb05216.x

Pitzl, M.-L. (2009). "We should not wake up any dogs": Idiom and metaphor in ELF. In A. Mauranen \& E. Ranta (Eds.), English as a Lingua Franca: Studies and findings (pp. 298-322.). Newcastle upon Tyne: Cambridge Scholars Publishing.

Raedts, M., \& Roozen, I. (2015). De terughaalactie geld alleen voor de hierboven afgebelede pizza's geldig. Het effect van taalfouten in product recall-advertenties. Tijdschrift voor Communicatiewetenschap, 43(3), 292-312.

Rifkin, B., \& Roberts, F.D. (1995). Error gravity: A critical review of research design. Language Learning, 45(3), 511-537. https://doi.org/10.1111/j.1467-1770.1995.tb00450.x

Roberts, F., \& Cimasko, T. (2008). Evaluating ESL: Making sense of university professors' responses to second language writing. Journal of Second Language Writing, 17, 125-143. https://doi.org/10.1016/j.jslw.2007.10.002

Seidlhofer, B. (2011). Understanding English as a Lingua Franca. Oxford: Oxford University Press. 
Sheorey, R. (1986). Error perceptions of native-speaking and non-native speaking teachers of ESL. ELT Journal, 40(4), 306-312. https://doi.org/10.1093/elt/40.4.306

Smakman, D., Korzilius, H., van Meurs, F., \& van Neerven, E. (2009). English words and phrases in radio commercials in the Netherlands: Their use and effects. ESP across Cultures, 6, 107-128.

Spillner, B. (2017). Error analysis in the world. A bibliography. Berlin: Frank \& Timme GmbH.

Stiff, C. (2012). Watch what you write: How errors in feedback influence consumer attitudes and behavior. Journal of Internet Commerce, 11(1), 41-67. https://doi.org/10.1080/15332861.2012.650988

Tetreault, J. R., \& Chodorow, M. (2008). The ups and downs of preposition error detection in ESL writing. Proceedings of the COLING '08 22nd International Conference on Computational Linguistics (Vol 1) (pp. 865-872). Retrieved June 20, 2018, from http://dl.acm.org/citation.cfm?id=1599190

Vignovic, J. A., \& Thompson, L. F. (2010). Computer-mediated cross-cultural collaboration: Attributing communication errors to the person versus the situation. Journal of Applied Psychology, 95(2), 265-276. http://dx.doi.org/10.1037/a0018628

\section{Appendix: Stimulus text used in the experiment}

Have you had enough of the government meddling in your downloading behaviour? Are you sick and tired of the *music- and film industry's [music and film industry's] lawsuits against websites and downloaders? If so, please sign our petition now!

We at FreeSurfer advocate free and legal downloading of content from the Internet. The industry needs to understand that downloading * gets [is getting] more and more important to people and it is not realistic to *aspect [expect] them to stop overnight. On the other hand we all know the *music- and film industry [music and film industry] * suffers [is suffering] a lot these days through websites * $\underline{\text { as }}$ [such as] Youtube and PirateBay. FreeSurfer wants to convince the lawmakers and media-related institutions * for [of] the necessity of a legal framework to download music and films freely.

FreeSurfer and the *music- and film industry [music and film industry] will cooperate by reaching a compromise that will be mutually * benifitial [beneficial] if FreeSurfer collects over *500.000 [500,000] signatures from people who are interested!

More than $* 10.000[10,000]$ people have already signed this petition. Please follow their lead and show your support by signing this petition and supporting our fight to keep downloading legal and free!

To sign the petition, please go to www.freesurfer.org.

Note: *error version, [correct version] 